\title{
THE EFFECT OF METALINGUISTIC WRITTEN CORRECTIVE FEEDBACK ON ENGLISH WRITING COMPETENCY OF THE EIGHTH GRADE STUDENTS OF SMPN 1 ABIANSEMAL IN ACADEMIC YEAR 2015/2016
}

\author{
S. A. Gasella, D.P. Ramendra, I N. P. Hadisaputra \\ Jurusan Pendidikan Bahasa Inggris \\ Universitas Pendidikan Ganesha \\ Singaraja, Indonesia \\ e-mail: sintaarygasella@gmail.com, dewaramendra@yahoo.com, \\ pasek hadisaputra@yahoo.com
}

\begin{abstract}
Abstrak
Penelitian ini bertujuan untuk mengetahui apakah terdapat perbedaan signifikan pada kemampuan menulis siswa kelas delapan SMP yang diberikan metalinguistic written corrective feedback dan siswa yang tidak diberikan feedback. Penelitian experimental ini mengambil kelas VIII yaitu kelas VIII B sampai VIII F sebagai populasi dan sampel kelas VIII B dan VIII F yang dipilih melalui cluster random sampling, dimana kelas VIII B sebagai kelompok control dan kelas VIII F sebagai kelompol eksperimen. Desain penelitian ini adalah pretes-postes kontrol group.Data yang diperoleh yaitu nilai pretes dan postes siswa yang kemudian dianalisis dengan deskriptif statistik dan inferensial statistik.Dalam pengujian hipotesis, digunakan analisis ANACOVA dalam SPSS 17.0.Berdasarkan hasil uji ANACOVA, didapakan nilai signifikan pada kelompok adalah 0.024 yang merupakan lebih tinggi dari tingkat signlfikan 0.05 . Hal tersebut berarti terdapat perbedaan yang signifikan antara kelompok eksperimen dengan kelompok kontrol, maka hipotesis nul ditolak.Berdasarkan hasil analisis, dapat disimpulkan bahwa terdapat dampak berbeda antara siswa yang diberikan metalinguistic written corrective feedback dengan siswa yang tidak mendapakan feedback.
\end{abstract}

Kata kunci: Metalinguistic Written Corrective Feedback, Kompetensi Menulis

\begin{abstract}
The present study aimed at investigating whether or not there was a significant difference in writing competency between the eighth grade junior high school students who received metalinguistic WCF and those who did not receive any feedback. This experimental study took the eighth grade students in SMPN 1 Abiansemal as the population and VIIIB and VIIIF respectively as the control and experimental group through cluster random sampling. The design of the study was pretest-posttest control group design. The data were the students' pretest and posttest that were analyzed descriptively and inferentially. ANCOVA test was used in analyzing the data and to test the hypothesis. The result of the analysis using ANCOVA in SPSS 17.0 showed that the significance value of the group was 0.024 which was lower than the significance level 0.05 . It means that the null hypothesis was rejected. It was concluded that there was a significant difference between students who received metalinguistic WCF and those who did not receive any feedback.
\end{abstract}

Keywords :Metalinguistic Written Corrective Feedback, Writing Competency 


\section{INTRODUCTION}

Giving correction on students' writing errors is an issue arisen since researchers have begun to debate whether it is helpful or not on students' writing. The correction given on students' writing is known as written corrective feedback in teaching writing technique. Correction or corrective feedback given on students writing aims to be helpful in enhancing students' writing competency.

By correcting the errors made, it is expected that the students will not do the same error and develop their writing. On the other hand, there is argument that correction given has a certain side effect that students feel hesitate to write. The two opposite perspectives regarding written corrective feedback have existed. The proponent of written corrective feedback claims that written corrective feedback is effective for teaching writing and able to students' writing competency, whereas the opponent consider written corrective feedback is ineffective, even harmful.

It had been divided the opponents which included Knoblauch \& Brannon, 1981; Hillocks, 1986 (as cited in Truscott, 1996); Sheppard, 1992; Polio, Fleck \& Leder, 1998; Hendrickson, 1978; Krashen, 1992; Leki, 1990; Van Patten, 1986a, 1986b (as cited in Truscott, 1996) and Fazio, 2001), who refuted the positive influence of CF and the proponents were Van Beuningen, De Jong, \& Kuiken, 2012; Farid \& Samad, 2012; Ahmadi, Maftoon \& Mehrdad, 2012; Bitchener \& Knoch, 2010; Bitchener, Young \& Cameron, 2005; Bitchener \& Knoch, 2009; Ellis, Sheen, Murakami \& Takashima, 2008; Ferris \& Roberts, 2001; Tuzi, 2004; Yeh \& Lo, 2009 and Ferris, 1999, who strongly suggested teachers to apply CF in their writing teaching to help students in their performance. These two points of view were still controversial because they both had their own research and supporting evidence.
In order to get the clear evidence of the effect of written corrective feedback on writing competency, the researcher who had interest in teaching writing still conduct researches investigating the effect written corrective feedback towards students' competency in writing.

Rod Ellis (2009) had done a research to examine the effect of each kind of written corrective feedback on writing. The study resulted that the type of corrective feedback which was most effective depended on what kind errors existed. Moreover, there was a yet no clear evidence to which of three major types of strategies (direct, indirect, or metalinguistic) was the most effective.

Mohebbi (2013) had carried out a study on written corrective feedback on second language writing. The study resulted there has been a great deal of arguments for and against the efficacy of implementing written corrective feedback on enhancing second language writing, yet there is little available to reach to a firm conclusion.

Another research was done by Azizi, Behjat, and Sorahi (2014) on investigating the effect of metalinguistic written corrective feedback. The sample of this study was 69 female students at a high school in Eghlid, Iran. Results showed that the metalinguistic type written corrective feedback, especially description mode had a positive influence on the writing improvement of the Iranian EFL students. Though, there was research which proven that by giving feedback was helpful for students in writing, it still compulsory to investigate the effect of written corrective feedback on students writing competency in different sample.

Since giving correction is a common technique implemented in teaching writing, particularly in responding students' writing performance, the effect of written corrective feedback was compulsory to be investigated in order to have clear evidence whether it was effective or harmful toward students. 
Written corrective feedback used to be investigated among intermediate and advance learner of second language and foreign language, the novice level needs to be observed on its respond to this technique in writing, whether it is helpful or harmful.

Writing is one competency that is taught in school based curriculum in Indonesia. It causes mastering writing in English is a need by students. Junior high school students are novice level in English who needs a lot of guidance from teacher, especially in writing which acquires cognitive process. In producing a piece of writing, students needed guidance and help from the teacher, teacher could not leave students themselves to do writing. in this case, the guidance given from teacher were in form of the correction and comments on students' errors in writing. The correction and comments are corrective feedback. So, the teacher should have clear idea about whether giving the corrective feedback on students writing errors would be helpful and beneficial for students or harmful and made students hesitate to write.

$$
\text { Based on the preliminary }
$$

observation done in junior high schools in Abiansemal, it was found that the difficulty in enhancing students' writing competency was still faced recently. It became a problem in teaching writing to students. The problem was also found in SMP Negeri 1 Abiansemal. The school uses school based curriculum where writing is one of the competencies in English learning. Teaching writing for students was considered complicated by teacher. It is caused by writing needs students cognitive process, so the teacher needs to implement effective method and strategy in teaching writing. In practicing how to write in the target language, students need the guidance from the teacher. In fact, there were found that in teaching writing, teacher was simply giving students task to write on a particular topic but did not give any feedback on students' performance in writing. Even though teacher gave comments or feedback on students' writing, it was leaved on that stage; without asking the students' respond on the feedback. The students did not have any confirmation if they had errors of not on their writings.

Moreover, in conducting this study, the errors of students' writing was assumed to exist or they did exist. Based on the preliminary observation on students' writing task, the errors did exist. Indeed, the teacher did not give feedback to all classes but only if the teacher had time. It made unclear effect of written feedback given to students' writing. Moreover, there several mistakes that teacher committed in giving feedback on students' writing, for instance, the teacher did not ask the students' uptake toward the feedback given.

Based on the preliminary observation, the researcher conducted the study in SMPN 1 Abiansemal. Then, from reviewing the empirical studies on written corrective feedback, the researcher chose metalinguistic written corrective feedback since it had not been investigated in number of studies, in fact there were studies on metalinguistic written corrective feedback, it was done in intermediate and advance learner.

Metalinguistic written corrective feedback involves providing learners with some forms of explicit comment about the errors they have made (Ellis, 2008). Metalungistic written corrective feedback is explicit and direct feedback which guides students straight to errors they have made. Metalinguistic written corrective feedback consists of two form of feedback, namely error code and brief grammar explanation.

Investigating the effect of written corrective feedback on students' writing competency has two kinds of type. There are short term effect of written corrective feedback and long term effect of written corrective feedback. Since metalinguistic WCF is explicit and direct WCF, it guide the researcher to investigate the short term effect of WCF on writing competency of junior high school students. This study investigated only one kind of writing, it was recount text. 


\section{METHOD}

This research is an experimental research. The population of this stuy was eighth grade students from Class VIIIB to VIIIF in SMPN 1 Abiansemal in the academic year 2015/2016 In doing the study, the first step was proving that population was insignificantly different in their english competency. The ANOVA test was run to prove the population was insignificantly different in their english competency. The insignificant different of English competency among the individuals in the population is one reqruitment of using random sampling. Cluster random sampling was done because of the indiviudals in the population has already grouped by the school regulation and could not be splitted. By using lottery, it was selected that VIIIB as the control group and VIIIF as the experimental group.

There were two variable in the present study. The independent variable was metalinguistic written corrective feedback. The dependent variable was writing competency.

The design of the study is pretestposttest control group design. Before giving the treatment, both groups were prettested to know their earlier competency in writing in English. After given pretest, both groups were treated by process approach for teaching writing, the difference was the feedback in which control group recieved no feedback and experimental group recieved metalinguistic writtent corrective feedback. When the treatments were done, both groups were posttested to know their writing competency after given different treatment.

This study investigated the short term effect of metalinguistic written corrective feedback. This study was focused on one writing genre to be investigated; it was recount text. One treatment (process approach with metalinguistic written corrective feedback or process approach with no feedback) was completely accomplished in two meeting in a week. The students were given treatment twice. They had produced two recount texts in different topic.

The instruments in collecting the data (writing tests) were testesd its validity and reliability. The validity of the instruments was measured using Gregory's Formula for testinng validity. The reliability of the instrumenst was measured using Hyot's Formula. After the tests (pretest test and posttest test) were valid and reliable, it was used to collect the data.

After the process of pretesttreatment-posttest, the data were collected to be analyzed. The data of students' pretest and posttest were analyzed descriptively and inferentially. Descriptive statistics used to measuring the mean, median, range, standard deviation, and variance of students' scores.

The inferential statistics used to test the hypothesis of the study. This students proposed null hypothesis which stated that theres is no significant difference between students who were give metalinguistic written corrective feedback and students who were not given any feedback. The inferential statistics used was parametric statistics. ANCOVA/ANACOVA (Analysis of Covariance) was used to control the covariate in affecting the posttest and measuring the change of the samples based on the treatment alone. In using ANCOVA test, there are four reqruitment tests namely normality test, homogeneity test, linearity test, and regression test. If the result of the significance value is higher than significance level 0.05 , null hypothesis is accepted

\section{FINDINGS}

The data in this study were content from the result of students' pretest and posttest in form of students' score on writing. The data were analyzed descriptively and inferentially. Based on the data of students pretest and posttest, it resulted that the description of the data as follows: 
Table 1. The Result of Descriptive Analysis of Pretest

\begin{tabular}{|c|c|c|}
\hline \multirow[b]{2}{*}{$\begin{array}{l}\text { Stati } \\
\text { stic }\end{array}$} & \multicolumn{2}{|c|}{ Pretest } \\
\hline & $\begin{array}{l}\text { Cont } \\
\text { rol Group }\end{array}$ & $\begin{array}{l}\text { Experi } \\
\text { mental } \\
\text { Group }\end{array}$ \\
\hline Mea & $\begin{array}{ll} & 52.1 \\
3\end{array}$ & 69.00 \\
\hline an $\quad$ Medi & $\begin{array}{ll} & 52.0\end{array}$ & 70.00 \\
\hline $\mathrm{e} \quad$ Rang & 28.0 & 35.00 \\
\hline nce Varia & 59.6 & 45.61 \\
\hline $\begin{array}{l}\text { Stan } \\
\text { dard } \\
\text { Deviation }\end{array}$ & 7.72 & 6.75 \\
\hline
\end{tabular}

Table 2. The Result of Descriptive Analysis of Pretest

\begin{tabular}{|c|c|c|}
\hline \multirow[b]{2}{*}{$\begin{array}{l}\text { Stat } \\
\text { istic }\end{array}$} & \multicolumn{2}{|c|}{ Posttest } \\
\hline & $\begin{array}{l}\text { Contr } \\
\text { ol Group }\end{array}$ & $\begin{array}{l}\text { Experi } \\
\text { mental } \\
\text { Group }\end{array}$ \\
\hline n $\quad$ Mea & 81.15 & 82.37 \\
\hline ian $\quad$ Med & 82.00 & 82.00 \\
\hline ge Ran & 25.00 & 28.00 \\
\hline ance $^{\text {Vari }}$ & 44.60 & 51.90 \\
\hline $\begin{array}{l}\text { Sta } \\
\text { ndard } \\
\text { Deviation }\end{array}$ & 6.67 & 7.20 \\
\hline
\end{tabular}

Based on the Table 1, the mean score of the pretest of control group was 52.13 and the experimental group was 69.00. then on the posttest result, the mean score of control group was 81.15 and experimental group was 82.37.

The difference of the mean score of pretest of control group (52.13) and (69.00) was significant. Then the ANCOVA/ANACOVA test was used in order to adjusted the scores of control group to remove the initial advantage, so the end of the study the result can be fairly compared, as if the two groups started equally (Gay, Mills, \& Airasian, 2009:223).
The ANCOVA test was aimed to control the covariate variable so that it would not affect the result of the posttest.

There are four recruitments test prior the testing using ANCOVA test was done. There are test of normality, test of homogeneity, test of linearity, and test of regression.

The pretest and posttest data were normally distributed in which based on the Kolmogorov-Smirnov test, the significance values of pretest of control group was 0.200 , the same as pretest of the experimental group. Significance values of posttest of both control and experimental group were the same (0.200). the result of the Kolmogorov-Smirnov test can be seen on the Table 3.

Table 3. The Result of Normality Test

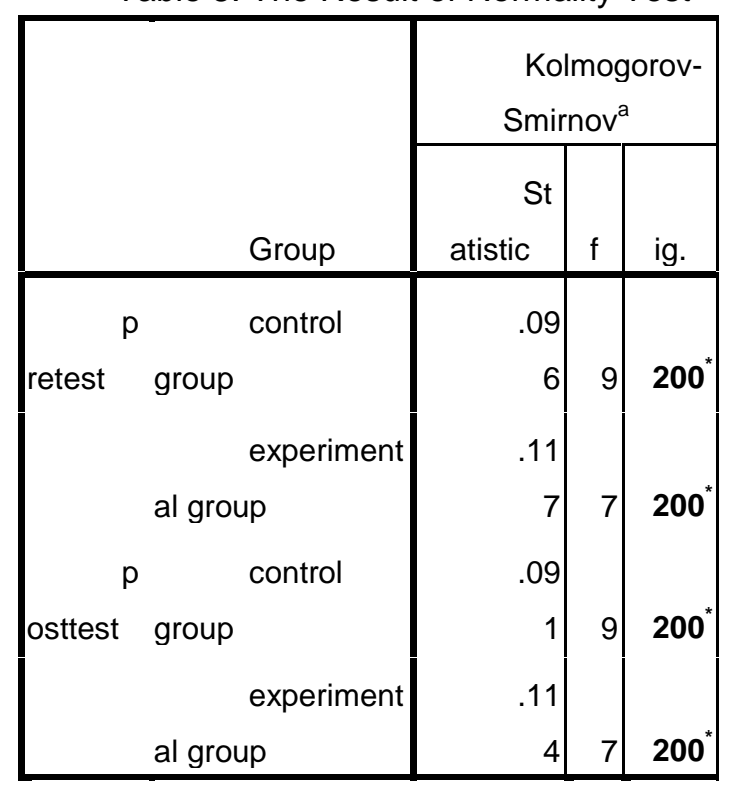

a. Lilliefors Significance

Correction

${ }^{*}$. This is a lower bound of the true significance.

It was classified as normally distributed data because the significance values (0.200) was higher than significance level (0.05).

Test for homogeneity was done using Levene Statistic test of variance, it resulted that significance value based on mean of pretest data was 0.161 and significance value based on mean of posttest was 0.825 . The result of the 
Levene Statistic test is showed on the table 4 .

Table 4. The Homogeneity Test

\begin{tabular}{|c|c|c|c|c|}
\hline & $\begin{array}{l}\text { Le } \\
\text { vene } \\
\text { Statistic }\end{array}$ & 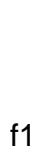 & f2 & ig. \\
\hline 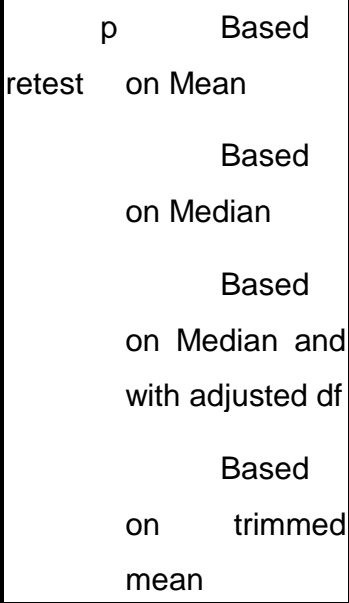 & $\begin{array}{r}2 . \\
006 \\
2 . \\
004 \\
\\
2 . \\
004 \\
\\
2 . \\
009\end{array}$ & & 3.356 & $\begin{array}{r}161 \\
161\end{array}$ \\
\hline $\begin{array}{c}\text { p } \quad \text { Based } \\
\text { osttest } \text { on Mean } \\
\text { Based } \\
\text { on Median } \\
\text { Based } \\
\text { on Median and } \\
\text { with adjusted df } \\
\text { Based } \\
\text { on trimmed } \\
\text { mean }\end{array}$ & $\begin{array}{r}.0 \\
49 \\
.0 \\
43 \\
.0 \\
43\end{array}$ & & 2.983 & 824 \\
\hline
\end{tabular}

Based on the result, all the significance values are higher than significance level 0.05 . Tt meant that the data were homogeneous.

The linearity test was done using ANOVA test for linearity. The result of linearity test is presented on the Table 5.
Table 5. The Linearity Test

\begin{tabular}{|c|c|c|c|c|}
\hline & & \begin{tabular}{|c|} 
M \\
ean \\
Square
\end{tabular} & & ig. \\
\hline $\begin{array}{c}\text { p } \\
\text { osttest * etween } \\
\text { pretest Groups }\end{array}$ & $\begin{array}{l}\text { (Com } \\
\text { bined) } \\
\text { arity } \\
\text { Devi } \\
\text { ation from } \\
\text { Linearity } \\
\text { W Withi } \\
\text { n Groups }\end{array}$ & $\begin{array}{r}5 \\
6.561 \\
3 \\
83.759 \\
4 \\
2.928 \\
\\
4 \\
3.564\end{array}$ & $\begin{array}{l}.298 \\
.809 \\
985\end{array}$ & $\begin{array}{l}213 \\
005 \\
500\end{array}$ \\
\hline
\end{tabular}

The results were significance value of Linearity between groups (0.005) was lower than 0.05 and significance value of Deviation from Linearity (0.500) was higher than 0.05 . It meant that the data were linear.

Test for regression was done with Univariate Analysis of Variance with the result was significance value of group*pretest was (0.068) higher than 0.05 .

Tests of Between-Subjects Effects

Dependent Variable:posttest

\begin{tabular}{|c|c|c|c|c|c|}
\hline $\begin{array}{ll} & \text { So } \\
\text { urce } & \end{array}$ & $\begin{array}{l}\text { Type } \\
\text { III Sum of } \\
\text { Squares }\end{array}$ & $f$ & $\begin{array}{c}\text { M } \\
\text { ean } \\
\text { Square }\end{array}$ & & ig. \\
\hline Col & 739.3 & & 24 & & \\
\hline rected & $35^{\mathrm{a}}$ & & 6.445 & .220 & 001 \\
\hline Model & & & & & \\
\hline Inte & 2927. & & 29 & & \\
\hline rcept & 612 & & 27.612 & 3.885 & 000 \\
\hline Pre & 651.4 & & 65 & & \\
\hline test & 79 & & 1.479 & 6.442 & 000 \\
\hline Grc & 198.2 & & 19 & & \\
\hline up & 50 & & 8.250 & .003 & 028 \\
\hline gro & 136.5 & & 13 & & \\
\hline up & 33 & & & .446 & 068 \\
\hline pretest & & & & & \\
\hline
\end{tabular}




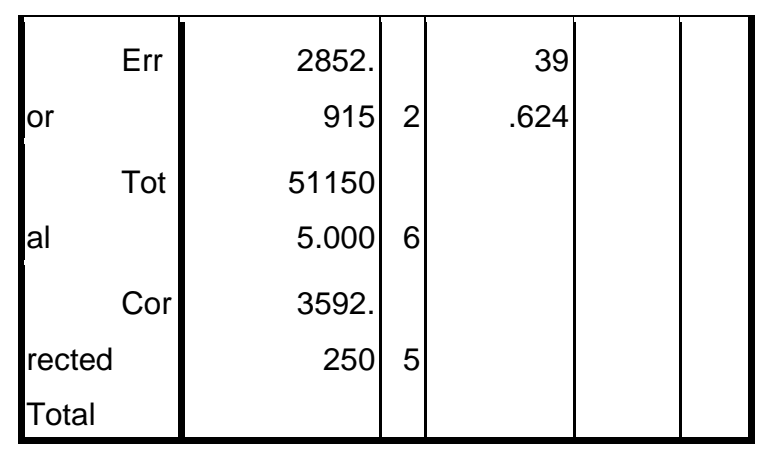

a. R Squared $=.206$ (Adjusted R Squared $=$ $.173)$

Based on the output of the analysis of ANOVA, it resulted that the significance value of group*pretest was higher than significance value 0.05 . It meant that the covariate (prior ability; pretest) would not give initial advantage so the posttest result could be fairly compared.

All of the recruitment tests showed that the data could be tested using ANCOVA test. The data of pretest and posttest was analyzed with ANCOVA test inn SS type III using SPSS 17.0. The output of the analysis is presented on the table 7.

Based on the output, it was shown that the significance value of Pretest is 0.000 . It was lower than 0.05 , it meant Ho was rejected. In the $95 \%$ of significance, it could be stated that there was a linear interaction between pretest and students' posttest. This indicated that ANCOVA test assumption was fulfilled. This test was used to omit the difference of the pretest in affecting the students' posttest.

It was continued in analyzing the difference treatment in affecting students' posttest. It was done by omitting the initial advantage of students' pretest, from the output, it was shown that the significance value of Group was 0.024 in which lower than the significance level 0.05 . It meant Ho (null hypothesis) was rejected.

It can be concluded that, without any effect of students' pretest, in 95\% significance, there was a difference of students' posttest between both groups.

Tabel 7. The Result of ANCOVA Test

\begin{tabular}{|c|c|c|c|c|c|}
\hline $\begin{array}{l}\text { Sou } \\
\text { rce }\end{array}$ & $\begin{array}{l}\text { Type III Sum of } \\
\text { Squares }\end{array}$ & $d f$ & $\begin{array}{l}\text { Mean } \\
\text { Square }\end{array}$ & $F$ & Sig. \\
\hline $\begin{array}{l}\text { Corr } \\
\text { ected } \\
\text { Model }\end{array}$ & $602.802^{\mathrm{a}}$ & 2 & 301.401 & 7.360 & .001 \\
\hline $\begin{array}{l}\text { Inter } \\
\text { cept }\end{array}$ & 3602.127 & 1 & 3602.127 & $\begin{array}{r}87.96 \\
1\end{array}$ & .000 \\
\hline $\begin{array}{l}\text { Pret } \\
\text { est }\end{array}$ & 574.332 & 1 & 574.332 & $\begin{array}{r}14.02 \\
5\end{array}$ & .000 \\
\hline up $^{\text {Gro }}$ & 219.043 & 1 & 219.043 & 5.349 & .024 \\
\hline Erro & 2989.448 & 73 & 40.951 & & \\
\hline$I^{\text {Tota }}$ & 511505.000 & 76 & & & \\
\hline $\begin{array}{l}\quad \text { Corr } \\
\text { ected } \\
\text { Total }\end{array}$ & 3592.250 & 75 & & & \\
\hline
\end{tabular}

It meant that there was significant difference between students who were given metalinguistic written corrective feedback with students who were given no feedback on their writing.

\section{DISCUSSION}

This study investigated the effect of metalinguistic written corrective feedback on students' writing competency in short term effect. There were four meeting for 
treatments which consisted of two treatments. The pretest was administered for both groups so that it enabled to know the ability on writing of both groups. Then, along the treatment, both experimental and control group were taught by implementing process approach for teaching writing. The steps of process approach used in this study were based on Tribble in Badger and White (2000) the steps were: prewriting; drafting /composing; revising; and editing. Both groups were given the same process approach, only the difference was on the feedback in which the experimental group received metalinguistic written corrective feedback and control group received no feedback.

One set of process approach steps was accomplished in two meeting with one topic of lesson. There were two process approach and two topics in the present study.

In the control group student at first were introduced to recount text, as if students fully understand about the recount text, the researcher gave modeling about prewriting by selecting a topic, the making a draft, the compose a text based on the draft, it was followed by revising and the last editing. The students worked on their writing alone, but the researcher still gave guidance and help.

The experimental group received the explanation about recount text followed by modeling about steps in producing a text based on the process approach the same as the control group. The students in the experimental group were given metalinguistic written corrective feedback. The kinds metalinguistic WCF that given on students' writing were error codes and brief grammar explanation. Giving the metalinguistic written corrective feedback were based on the aspects of writing that the researcher accessed by the writing rubrics adopted from Arthur Hughes (1989). The writing rubric consisted of five dimension or aspects, namely content, organization, grammar, diction or vocabulary, and mechanis. Those five dimensions were used as guidance in correcting students' errors and waccessing the students' writing.
Besides the result of the pretest and posttest as the data of students' writing competency, the researcher also calculated the students' writing scores in the treatment I and treatment II. The calculation done was to know the mean score of pretest, Treatments, and posttest. The result is presented $n$ the table below.

Table 4 The Mean Scores of Students' Writing

\begin{tabular}{|l|c|l|l|l|}
\hline & $\begin{array}{c}\text { Pretes } \\
\mathrm{t}\end{array}$ & $\begin{array}{c}\text { Treatmen } \\
\mathrm{t} \mathrm{I}\end{array}$ & $\begin{array}{c}\text { Treatmen } \\
\mathrm{t} \mathrm{II}\end{array}$ & $\begin{array}{c}\text { Posttes } \\
\mathrm{t}\end{array}$ \\
\hline $\mathrm{C}$ & 52.52 & 67.76 & 76. & 81.15 \\
$\mathrm{G}$ & & & 28 & \\
\hline EP & 69.00 & 74.71 & 82.64 & 82.37 \\
\hline
\end{tabular}

Based on the calculation, the mean score on pretest, the experimental group was higher than control group. The mean score of the experimental group in the first treatment (treatment I) was higher than the control group. The mean score of the experimental group in the second treatment (treatment II) was higher than the control group. On the posttest, the experimental group gained the higher mean score than the control group. The representation of the mean scores of the control and experimental groups were presented on the graphic 1 .

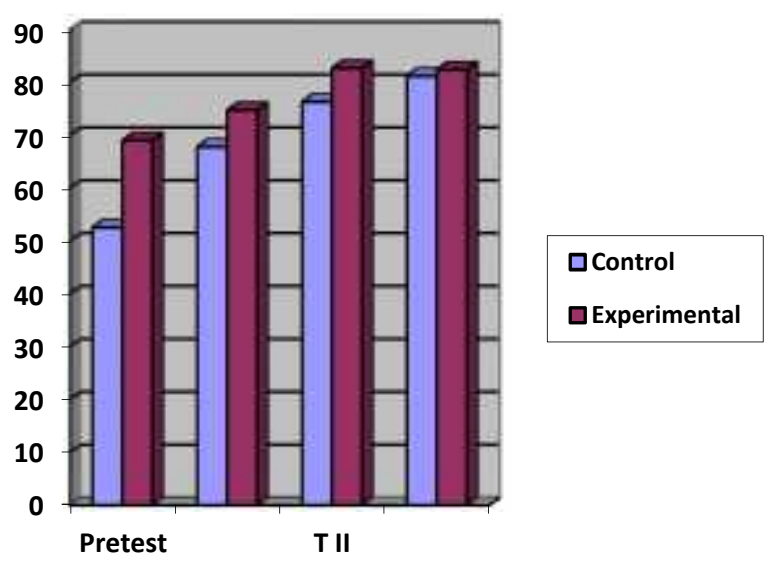

Based on the data, it was showed that the experimental group achieved more than the control group. It supported that there was effect on students writing competency taught by giving metalinguistic written corrective feedback.

Based on the students revised writing, it was found that students more easily revise the error which provided by 
brief grammatical explanation by the teacher. The grammatical explanation and description given was given focused on the generic structure on the recount text and it was found that students could easily build the writing with the right generic structure of the recount text. Meanwhile for aspects of grammar, diction, and mechanics, the researcher used error codes in giving corrective feedback.

It was supported by the result of the study done by Tootkaboni and Khatib (2014), it was found that it was beneficial to make use of direct written corrective feedback strategies when the short term period of mastery of the linguistic structure was needed and indirect written corrective feedback strategies were proposed when long term mastery of grammatical knowledge was the purpose of the educational intervention. In the present study, the aspect that contributed the most in increasing students' writing scores was the organization (generic structure of the text) which given brief grammatical explanation. The aspect of grammar which provided error codes took more than once revision to make students could correctly correct the error.

The result was in line with Azizi, Behjat, and Sorahi (2014), they compared the effectiveness of two types of metalinguistic feedback, error codes and brief explanation on students writing, in which they were three groups in their study, namely the control group, the experimental group with receiving error codes and the experimental group with receiving description feedback. The results showed that the metalinguistic types of written corrective feedback, especially description mode, had a positive influence on the writing improvement of the Iranian EFL students.

Ferris in Amara (2015) describe giving codes on students writing errors was indirect written corrective feedback, meanwhile giving brief grammatical explanation was direct written corrective feedback. Farris and Roberts in Amara (2015) did research in comparing two types of indirect feedback and it was found that students who received both underlying and coding in revising grammatical error were outperformed than those who received only underlining. It meant that the variation codes used in giving feedback on students error helped students easily noticed and revised the error. In this study, besides students received the brief grammatical explanation in which it helped students to easily understand the errors they have made, but various error codes used in indicating the errors in their writing was also beneficial for students even though not all the students could revise the error which provided with error codes.

It was also supported by the result of the study by Chandler (2003) which found thatboth direct correction and simple underlining of errors are significantly superior to describing the type of error, even with underlining, for reducing longterm error. Direct correction was best for producing accurate revisions, and students prefer it because it was the fastest and easiest way for them as well as the fastest way for teachers over several drafts. However, students felt that they learned more from self correction, and simple underlining of errors took less teacher time on the first draft. Both were viable methods depending on other goals. The result of Chandler's researcher, it against the Truscott's statement saying that written corrective feedback or giving correction on students' writing was wasting time, harmful for students, and making students' hesitate in writing and developing their idea in writing.

Based on the students development on the writing, it was found that the students produced less error that they used to produce in pretest and treatment I. Students did not hesitate to write, it was showed from the second writing in which they were given a new topic but the same text genre. They were able to express their idea into their writing. Then they were given metalinguistic written corrective feedback both error codes and brief explanation, they actively asked the teacher if they did not understand about the code.

It was supported by the result of the posttest; students were able to write a recount text with clear meaning, the 
correct organization, less grammar errors, proper diction, and correct mechanics. Comparing the students' pretest and posttest using ANCOVA test, it showed that significance value of group was 0.024 in which it was lower than significance level 0.05. It meant there was a significant difference between groups. The null hypothesis was rejected. It could be concluded that metalinguistic written corrective feedback had a positive effect on students writing competency.

Moreover, avoiding the design flaws, the design of the study was based on the considerations of Bitchener and Ferris (2012) views. The first was to establish the current performance level of a learner. The current performance level of students was in form of a piece of writing pretest. The second was the existence of the control group. According to Ellis, Sheen, Murakami, \& Takashima (2008) there were studies without control group (Chandler, 2000; Ferris, 1995, 1997, 2006; Lalande, 1982) reported improvement in grammatical accuracy following corrective feedback. The existence of control group could not be underestimated since the control group would enable to a comparison for students who received written corrective feedback and students who did not receive written corrective feedback (control group) then the findings could be used to answer the question of effectiveness. The third was measurement of improvement, comparable writing tasks needed to be administered at each test stage. Then, according to (Bitchener, (2008); Guénette, (2007), avoiding the use of different genres within a single study would have enabled valid text comparisons to be made in some of the early research. One genre of text could measure the improvement with compare the writing tasks rather than some text genres with different structures and language features. Those three considerations would help to access the clear result as evidence of the effectiveness of written corrective feedback.

Based on the discussion above, the result of this study could be taken as an evidence of the effectiveness of metalinguistic written corrective feedback on writing.

\section{CONCLUSION AND SUGGESTION}

Based on the results of the study, it concluded that the students who were given metalinguistic written corrective feedback on their writing errors performed better than the students who were not given any feedback. It was proven by the result that the significance value of Group was 0.024 which was lower than 0.05 . It meant that the null hypothesis is rejected. In other word, there was difference between groups who were given metalinguistic written corrective feedback and students who were not given any feedback.

There were some suggestions which can be proposed based on this study. The suggestions were giving written corrective feedback, particularly metalinguistic written corrective feedback was recommended for the teacher in teaching writing, especially for the genre of recount text. The feedback would give students guidance to the error they have made on their writing and by giving brief explanation about the error, the students will be able to revise the error or know the correct form and since the result of this study was applicable in limited samples and variables. It is suggested for the other researchers to conduct more elaborated study on written corrective feedback or metalinguitic written corrective feedback in order to develop this technique in teaching writing.

\section{ACKNOWLEDGEMENT}

This paper was supported by English Education Department of Ganesha University of Education and SMP Negeri 1 Abiansemal.

The thesis advisors, Dr. Dewa Putu Ramendra, S.Pd., M.Pd. and I Nyoman Pasek Hadisaputra, S.Pd., M.Pd., thank you for the valuable knowledge, suggestion, recommendation, advice, guidance, psychological support, and patience during the completion of this thesis. 
The all English Teachers of SMPNegeri 1 Abiansemal, Ms. Dian Kencana Dewi, Mrs. Oka, Mr. Subawa, and Mr. Suardika, thank you for guidance and valuable information related with the students and this study.

The students of VIII B and VIII F of SMP Negeri 1 Abiansemal, thank you for being the samples of the study with becoming very active learner in writing.

\section{REFERENCES}

Amara, T. (2015). Review of The Effectiveness of Written Corrective Feedback in an ESL Context. ELT Voice - India, volume, 5 (1), 34-44. ISSN: 2230-9136. Retrieved on July 10th, 2015 from http://www.eltvoices.in

Azizi, M., Behjat, F., \& Sorahi, M., A. (2014).Effect of Metalinguistic Teacher Corrective Feedback on Writing Performance of Iranian EFL Learners. International Journal of Language and Linguistics, ISSN: 2330-0221, 2(6), 54-63. Doi: 10.11648/j.ijll.s.2014020601.18Tootk aboniandKhatib

Bitchener, J. \& Knoch, U. (2008). The Value of Written Corrective Feedback for Migrant and International Students.Language Teaching Teacher, 12(3), 409-431. Doi: $10.1177 / 1362168808089924$

Eliis, R., Sheen, Y., Murakami, M., \& Takashima, H., (2008). The Effects of Focused and Unfocused Written Corrective Feedback in an English As a Foreign Language Context. Elsevier Journal, 2(1), 353-371. Doi:10.1016/j.system.2008.02.001

Gay, L. R., Mills, G. E., \& Airasian, P. (2009). Educational Research. New Jersey: Pearson Education.

Guenette, Danielle. (2007). Is feedback pedagogically correct? Research design issues in studies of feedback on writing. Journal of Second Language Writing, Volume 16, 4053.
Tookaboni, A.A. \& Khatib, M. (2014).The Efficacy of Various Kinds of Error Feedback on Improving Writing Accuracy of EFL Learners.Bellaterra Journal Teaching and Learning Language and Literature, 7(3), 3046. Retrieved from http://ddd.uab.cat/pub/jtl3/jtl3_a2014 m8-9v7n3/jtl3_a2014m8$9 v 7 n 3 p 30 . p d f$

Truscott, J. (1996). The Case Against Grammar Correction in L2 Writing Classes. Language Learning, 46, 327-369.Baggio, B. G. (2008). Creating supportive multimedia learning environment. Published Research Article in La Salle University, Philadelphia. Retrieved on January 20th, 2015 from http://www.irma-

\section{international.org/viewtitle/38280/}

